\title{
Karyological and gonadal sex of eels (Anguilla anguilla) from the German Bight and the lower River Elbe
}

\author{
T. Passakas ${ }^{1} \&$ F.-W. Tesch ${ }^{2}$ \\ ${ }^{2}$ Institute of Systematic and Experimental Zoology, \\ Polish Academy of Sciences; \\ 31-016 Kraków, Poland, \\ ${ }^{2}$ Biologische Anstalt Helgoland (Zentrale); \\ Palmaille 9, 2000 Hamburg 50, Federal Republic of Germany
}

\begin{abstract}
Yellow eels (Anguilla anguilla) taken during summer from random commercial trapnet samples in the littoral area of Helgoland $(n=116)$ and from a freshwater area of the River Elbe near Hamburg $(n=109)$ were examined with regard to their karyological (i.e. existence of female sex chromosomes) and gonadal sex. In $47 \%$ and $21 \%$ of the two samples, respectively, chromosomes were unidentifiable because of insufficient numbers of mitotic plates. All eels from Helgoland, except one phenotypically undetermined fish, exhibited female gonads: 48 had female sex chromosomes and 13 were karyologically males. As found previously in the River Elbe, eels with male gonads predominated $(n=55)$; 25 were undifferentiated. Of the gonadal males 26 were karyological males and 16 karyological females; the rest could not be identified by chromosome patterns. In contrast, all but one of the Elbe eels with female gonads ( $\mathrm{n}=28$ ) had female sex chromosomes. Some aspects of the sex reversal documented in the eel are considered.
\end{abstract}

\section{INTRODUCTION}

European yellow eels (Anguilla anguilla L.) caught in the open sea have an extremely high proportion of females (Peňáz \& Tesch, 1970; Löwenberg, 1979). This is also true for American silver eels (A. rostrata) originating from brackish water (Winn et al., 1975). However, in freshwater areas of the lower River Elbe males predominate (Peñáz \& Tesch, 1970; see review by Tesch, 1977), as is the case for American eels caught in fresh water adjacent to brackish-water areas (Winn et al, 1975). As shown by Peñáz \& Tesch (1970), females again predominate farther upstream (see also review by Tesch, 1977). Thus the highest proportion of male eels is found near the entrance of the river into the sea where population density is higher, and an increasing proportion of females is found from this point either farther up- or downstream. A steady increase of the proportion of females was also shown from 1910 to 1970 in the Baltic Sea (Svärdson, 1976). As population density and population pressure decreased, sex ratio changed in favour of the females. "The higher the population pressure, the more are the females stimulated to get away" (Svärdson, 1976). Tesch (1977), however, argues that a different migratory drive is an inadequate explanation for the sex distribution and sexual differentiation is not entirely dependent upon genotype.

A step toward the resolution of this problem can be made through the identification of chromosomes. Karyological investigations have shown the existence of a distinctly 
heteromorphic pair of female chromosomes in the eel (Ohno et al., 1973; Kang, 1974; Passakas, 1976; Park \& Kang, 1979). In the present study we have used the method described by Passakas (1976) to examine the chromosomes and the gonads of yellow eels from two samples of essentially different phenotypical sex relationships.

\section{MATERIAL AND METHODS}

109 unsorted yellow eels were obtained at the end of July 1977 from a commercial fisherman who caught them with trap nets in the fresh water of the River Elbe near Hamburg (at Wedel, $80 \mathrm{~km}$ from the river mouth). In September 1978 a commercial fisherman provided us with 116 yellow eels, caught with trap nets in the littoral area of the island Helgoland (North Sea):

The sex of gonads was first examined macroscopically. We removed and preserved as much squashed tissue as possible from both gonads, then examined it microscopically. This was particularly important for Elbe eels because many of their gonads were still undifferentiated (Pen̆áz \& Tesch, 1970; Saint-Paul, 1977).

We investigated the chromosomes of mitotic plates originating from gill epithelium. Fragments of gills were put into a $0.05 \%$ solution of colchicine; $1.5-2 \mathrm{~h}$ later they were transferred to a hypotonic solution for $1.5 \mathrm{~h}$. After fixation in $50 \%$ acetic acid for approximately $0.5 \mathrm{~h}$, the fragments were squashed under a pressure of $15 \mathrm{~kg} / \mathrm{cm}^{2}$. The cover glasses were removed by submersion in $70 \%$ ethyl alcohol, and the squashes were stained in Giemsa solution. We photographed the best metaphase plates for karyotype assessment (Fig. 1).

\section{RESULTS AND DISCUSSION}

The length-frequency distribution of karyological males and females each specifying the phenotypical sex as determined by examination of the gonads is shown in Figure 3. In both areas sex of a certain number of eels could not be determined by the

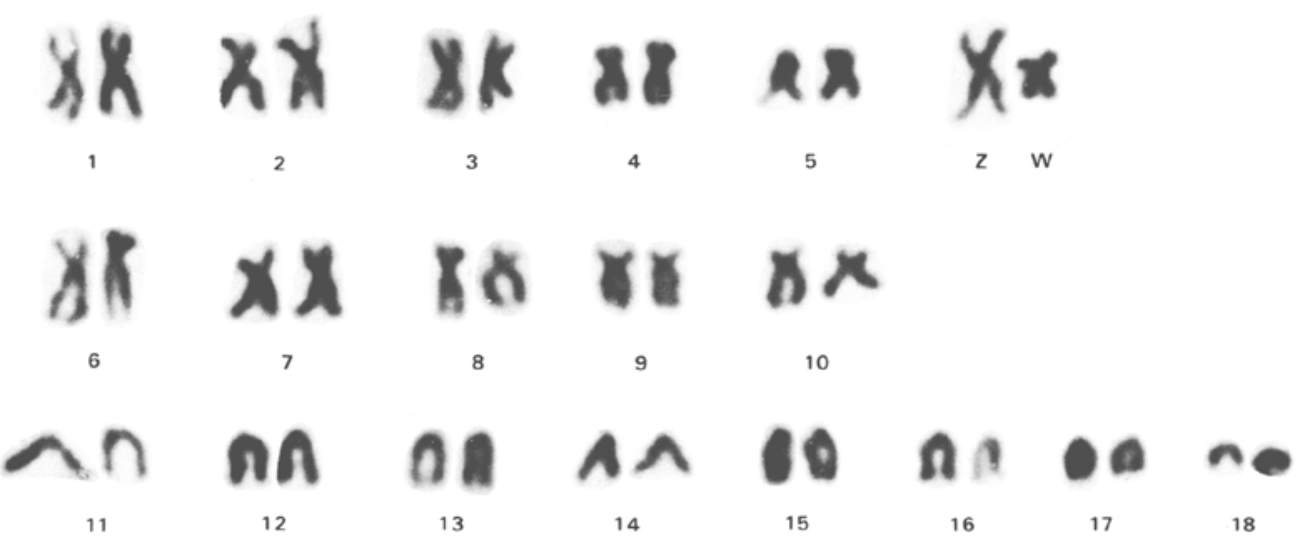

Fig. 1. Diploid set of Anguilla anguilla chromosomes $(2 \mathbf{n}=38) .1-5$ metacentric, 6 -10 submetacentric, 11-18 acrocentric pairs and a female heteromorphic pair with the largest and a small metacentric chromosome (ZW) 
karyological method because of insufficient quantities of mitotic plates. The proportion of these undeterminable eels was greater at Helgoland than in the River Elbe, possibly because the Helgoland eels were examined during a colder season (late summer to autumn) than the Elbe eels (mid-summer). Reddan et al. (1975) found June to August to be the best period for the study of mitosis in Opsanus tau.

All individuals examined revealed female gonads. This is consistent with the results of earlier investigations on eels from Helgoland (Peňáz \& Tesch, 1970; Saint-Paul, 1977; Löwenberg, 1979 unpublished). Karyologically, many of these eels were males which means that nearly all male eels changed into phenotypical females (Fig. 2).

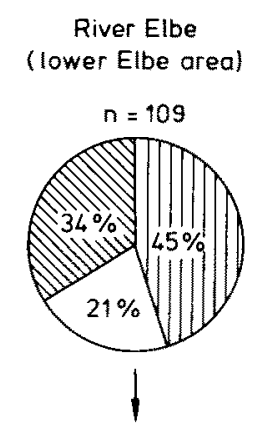

Determined from chromosomes

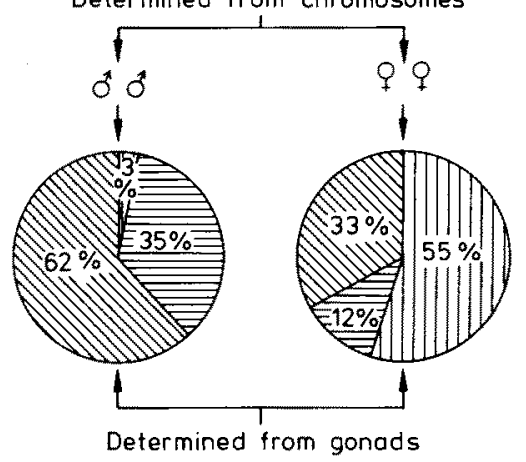

chromosomes not identified

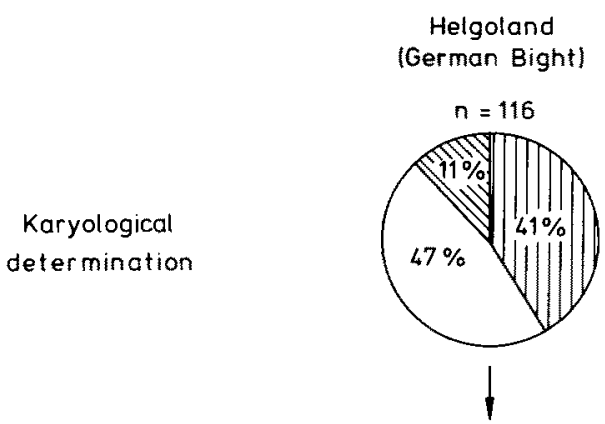

Determined from chromosomes

Gonadal determination

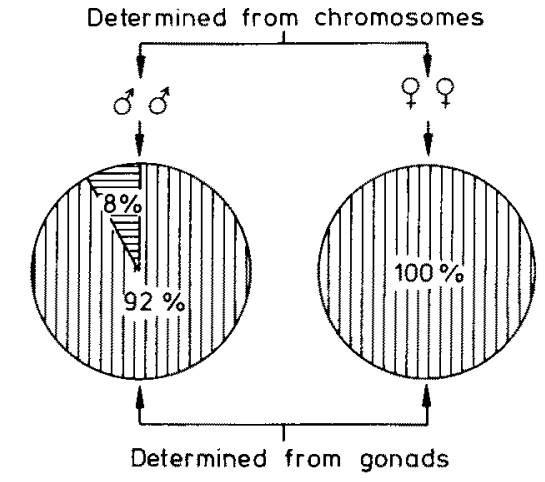

sexually not yet differentiated and hermaphrodites
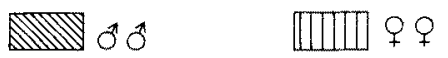

Fig. 2. Sex relationship (\%) of yellow eels (Anguilla anguilla) from Helgoland and the lower River Elbe determined by karyological methods and gonadal sex identification. Undetermined specimens include hermaphrodites

In the River Elbe, however, the results were quite different: many eels had male or undifferentiated gonads (Figs 2 and 3). This observation confirmed earlier results (Ehrenbaum \& Marukawa, 1914; Marcus, 1919; Wundsch, 1954; Peňáz \& Tesch, 1970; see Table 4 of Tesch, 1977). All karyological males except one (3\%) were shown to have developed male $(62 \%)$ or undifferentiated gonads. The karyological females, on the other hand, included a high proportion of phenotypical males $(33 \%)$. In addition, this unsorted sample of eels from the River Elbe showed a comparatively high number of 
3 mates (determined from chromosomes); of these, determined from gonads
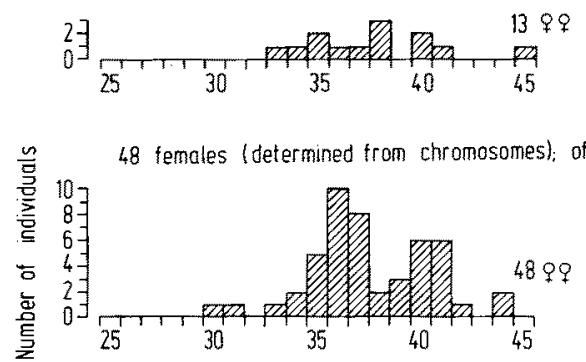

55 individuals (undetermined from chromosomes); of these, determined from gonads

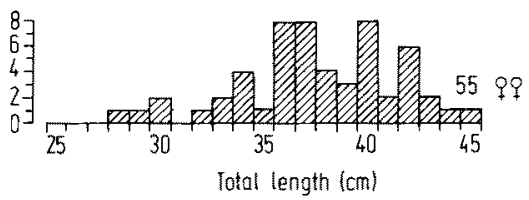

River Elbe (lower Elbe area, July 1977)

37 males (determined from chramosomes); of these, determined from gonads
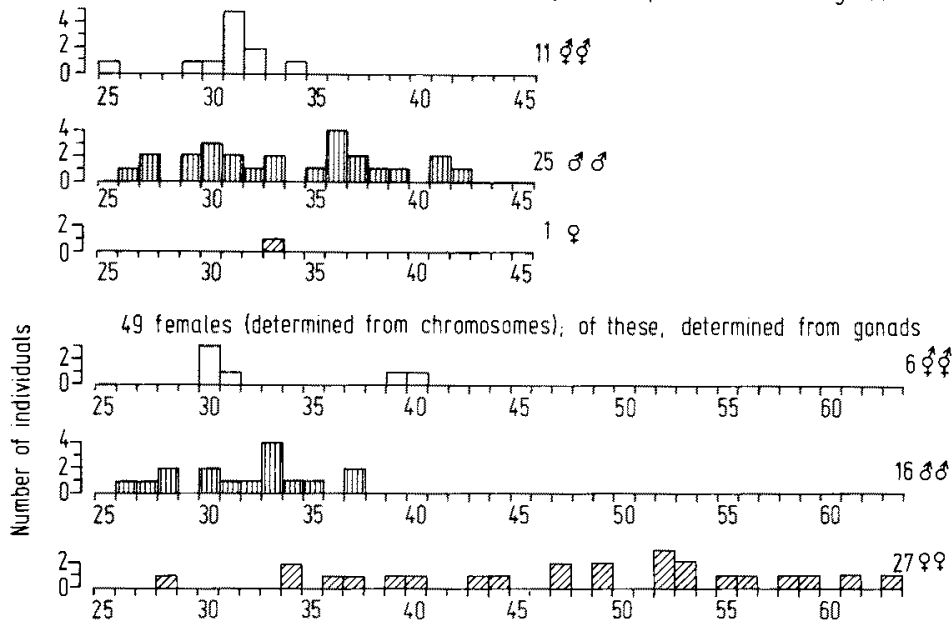

23 individuals (undetermined from chromosomes); of these, determined from gonads

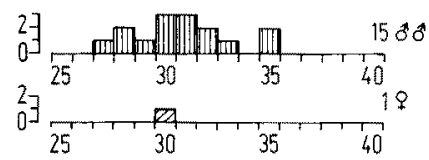

Total length (cm)

Fig. 3. Length frequency distribution of yellow eels caught near Helgoland in the lower River Elbe with specification of their karyological and gonadal sex. $\$ \$$ indicates undetermined or hermaphrodite gonadal sex. Of the 13 karyological Helgoland males with female gonads one specimen was not fully determined (length: $45 \mathrm{~cm}$ ) 
large female eels. If fish longer than $45 \mathrm{~cm}$ are discarded, the length frequency of the remainder is comparable with that of the Helgoland eels. The proportion of phenotypical female eels $(45 \%)$ then also decreases to $14 \%$, and this ratio compares with earlier results (Ehrenbaum \& Marukawa, 1914: $7 \%$ and $36 \%$; Marcus, 1919: $9 \%, 35 \%, 4 \%$, $29 \%$; Wundsch, 1954: $6 \%$ and $46 \%$; see Table 4 of Tesch, 1977). The samples of Wundsch (1954) consisted exclusively of small eels intended for transplantation into inland lakes and rivers.

Our results indicate that the genotypical glass eel females, which probably enter the continental waters at a normal sex ratio, stay in estuarine areas overcrowded with eels. Evidently, they then partly develop male gonads so that the number of male yellow eels is disproportionately high. The above-mentioned "population pressure" probably results more in malnutrition or other factors effecting a change of genotypical females into phenotypical males (Tesch; 1977, p. 57) than in an emigration of females (Svärdson, 1976).

Our investigations confirm the results of earlier aquacultural experiments that suggest a dependence of the phenotypical sex on population density, nutrition and/or other factors (J. J. Tesch, 1928; Gandolfi-Hornyold, 1932; Schnakenbeck, 1944; d'Ancona, 1950, 1957; Fidora, 1951; Kuhlmann, 1975). Origin (North Atlantic or Mediterranean) and size of the glass eels (Bellini, 1907; Kuhlmann, 1975) may have little or no significance for the aberrant sex ratio observed, since in the case of the estuarine areas of the Elbe the individuals studied were of the same origin and similar size.

In order to specify the factors involved in sex reversal, future research should focus on culture experiments under controlled conditions including the application of karyological methods. In addition, it will be necessary to examine the sex chromosomes of glass eels and leptocephali.

Hermaphroditism (sex reversal and undifferentiated gonochorism) is not unknown in teleosts (see Yamamoto, 1969) among which the eel is classified as an undifferentiated gonochorist. Experimental analysis of the genetic and phenotypical relationships in the sex expression of gonochoristic fishes has been presented, for example, in Oryzias latipes (Yamamoto, 1969) and Carasius auratus (Yamamoto \& Kajishima, 1968). Sex reversal can be induced in both species, which exhibit heterogamety in males. However, in the eel, the naturally occurring sex reversal is accomplished at heterogamety in females.

Acknowledgements. The authors wish to thank M. Bartel for technical assistance, Dr. O. Christians and Dr. B. Werner for providing gear, J. Marschall for drawing the figures, Prof. Dr. H.-P. Bulnheim for critically reading the text and making suggestions, $\mathrm{C}$. Schuster for typing the manuscript, and $\mathrm{S}$. Stansbury for assistance preparing the English text.

\section{LITERATURE CITED}

D'Ancona, U., 1950. Détermination et différenciation du sexe chez les poissons. - Archs Anat. microsc. Morph, exp. 39, 274-294.

D'Ancona, U., 1957. Nuove recerche sulla determinatione sessuale dell'anguilla (2. part.). - Archo Oceanogr. Limnol. 11, 69-111.

Bellini, A., 1907. Expérience sur l'élevage de l'anguille en stabulation a Comacchio. - Bull. Soc. cent. Aquic. Pêche 19, 81-93, 141-146, 186-196, 215-224. 
Ehrenbaum, E. \& Marukawa, H., 1914. Uber Altersbestimmungen und Wachstum beim Aal. - Z. Fisch. 14, 89-127.

Fidora, $M$., 1951. Influenza dei fattori ambientali sull accrescimento e sul differenziamento sessuale delle anguilla. - Nova Thalassia 1, 3-37.

Gandolfi-Hornyold, A., 1932. Le sexe de la petite anguille de repeuplement du Marais de la Grande Brière après un séjour de trois et quatre ans dans un aquarium du muséum. - Bull. Mus. Hist. nat., Paris 4, 64-70.

Kang, Y., 1974. A study on karyotypes of Anguilla japonica female heteromorphic chromosomes. Korean J. Zool. 1, 209.

Kuhlmann, H., 1975. Der Einfluß von Temperatur, Futter, Größe und Herkunft auf die sexuelle Differenzierung von Glasaalen (Anguilla anguilla). - Helgoländer wiss. Meeresunters. 27, $139-155$.

Löwenberg, U., 1979. Untersuchungen über den Aal in der Deutschen Bucht - Biologie und Fischerei. Diplom-Arbeit, Fachber. Biol. Univ. Hamburg, 107 pp.

Marcus, K., 1919. Uber Alter und Wachstum des Aales. - Mitt. hamb. zool. Mus. Inst. 36, 1-70.

Ohno, S., Christian, L., Romero, M., Dofuku R. \& Ivey, C., 1973. On the question of American eels, Anguilla rostrata, versus European eels, Anguilla anguilla. - Experientia 29, 891.

Park, E. H. \& Kang, Y, S., 1979. Karyological confirmation of conspicuous ZW sex chromosomes in two species of Pacific anguilloid fishes (Anguilliformes: Teleostomi) - Cytogenet. Cell Genet. 23, 33-38.

Passakas, T., 1976. Further investigations on the chromosomes of Anguilla anguilla. - Folia biol., Kraków 24, 239-244.

Peňáz, M. \& Tesch, F.-W., 1970. Geschlechtsverhältnis und Wachstum beim Aal (Anguilla anguilla) an verschiedenen Lokalitäten von Nordsee und Elbe. - Ber. dt. wiss. Kommn Meeresforsch. 21, $290-310$.

Reddan, J., Harding, C., Harding, D., Weinsieder, A., Unakar, N., Shapiro, R. \& Mathev, C., 1975. Seasonal mitotic activity and wound healing in a teleost (Opsanum tau) ocular lens. Experientia 31, 1026-1027.

Saint-Paul, U., 1977. Einige Aspekte der deutschen Satzaalfischerei. - Arch. FischWiss. 28, 123-133.

Schnakenbeck, W., 1944. Untersuchungen über Fragen um den Aal. - Z. Fisch. 42, 365-389.

Svärdson, G., 1976. The decline of the Baltic eel population. - Rep. Inst. Freshwat. Res. Drottningholm 55, 137-143.

Tesch, F.-W., 1977. The eel. Chapman \& Hall, London, 434 pp.

Tesch, J. J., 1928. On sex and growth investigations of the freshwater eel in Dutch waters. - J. Cons. perm. int. Explor. Mer 3, 52-69.

Winn, H. E., Richkus, W. A. \& Winn, I. K., 1975. Sexual dimorphism and natural movements of the American eel (Anguilla rostrata) in Rhode Island streams and estuaries. - Helgoländer wiss. Meeresunters. 27, 156-166.

Wundsch, H. H., 1954. Uber Alter und Geschlechtsverhältnisse bei dem zur Zeit im Handel befindlichen Satzaalmaterial. - Dt. FischZtg. Radebeul 1,9-15.

Yamamoto, T., 1969. Sex differentiation. In: Fish physiology. Ed. by W. S. Hoar \& D. J. Randall. Acad. Press, New York, 3, 117-175.

Yamamoto, T. \& Kajishima, T. 1968. Sex hormone induction of sex reversal in the goldfish and evidence for male heterogamy. - J. exp. Zool. 168, 215-222. 